\title{
SPRR2A wt Allele
}

National Cancer Institute

\section{Source}

National Cancer Institute. SPRR2A wt Allele. NCI Thesaurus. Code C114897.

Human SPRR2A wild-type allele is located within 1q21-q22 and is approximately $1 \mathrm{~kb}$ in length. This allele, which encodes small proline-rich protein $2 \mathrm{~A}$, is involved in cornified envelope formation. 